
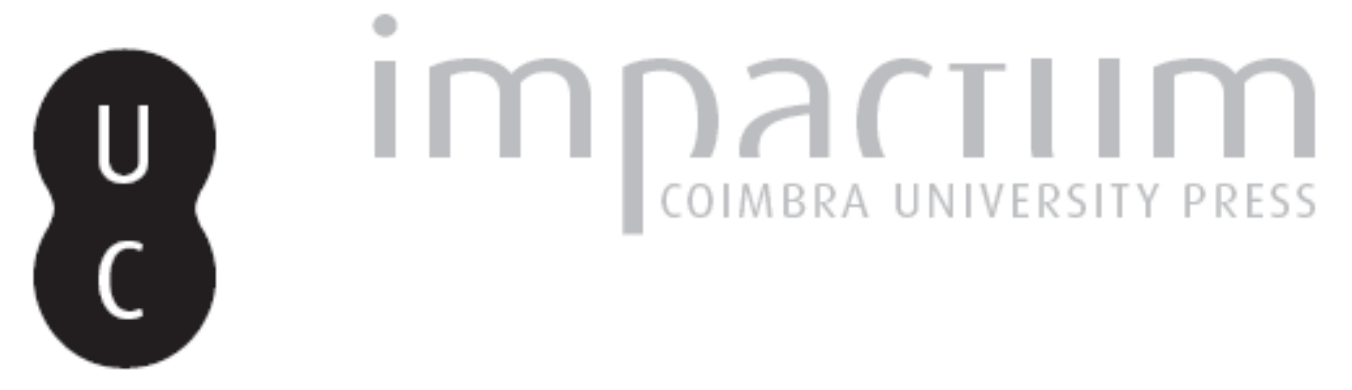

\title{
Health is wealth: Plutarch on contemporary luxury
}

Autor(es): $\quad$ Teodorsson, Sven-Tage

Publicado por: International Plutarch Society

URL persistente:

URI:http://hdl.handle.net/10316.2/37641

DOI:

DOI:http://dx.doi.org/10.14195/0258-655X_5_6

Accessed : $\quad$ 26-Apr-2023 14:07:59

A navegação consulta e descarregamento dos títulos inseridos nas Bibliotecas Digitais UC Digitalis, UC Pombalina e UC Impactum, pressupõem a aceitação plena e sem reservas dos Termos e Condições de Uso destas Bibliotecas Digitais, disponíveis em https://digitalis.uc.pt/pt-pt/termos.

Conforme exposto nos referidos Termos e Condições de Uso, o descarregamento de títulos de acesso restrito requer uma licença válida de autorização devendo o utilizador aceder ao(s) documento(s) a partir de um endereço de IP da instituição detentora da supramencionada licença.

Ao utilizador é apenas permitido o descarregamento para uso pessoal, pelo que o emprego do(s) título(s) descarregado(s) para outro fim, designadamente comercial, carece de autorização do respetivo autor ou editor da obra.

Na medida em que todas as obras da UC Digitalis se encontram protegidas pelo Código do Direito de Autor e Direitos Conexos e demais legislação aplicável, toda a cópia, parcial ou total, deste documento, nos casos em que é legalmente admitida, deverá conter ou fazer-se acompanhar por este aviso.

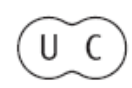




\title{
Health is wealth: Plutarch on Contemporary Luxury \\ by \\ Sven-Tage Teodorsson \\ Gothenburg University \\ Teodorsson@class.gu.se
}

\begin{abstract}
Plutarch's Platonic outlook made it natural for him not to regard wealth as an essential good. In addition his own strong commitment to ethics reinforced his conviction that if wealth is made an end in itself it will be pernicious to mental health and prevent a virtuous life. Furthermore, excessively rich people run the risk of ruining even their physical health through gormandizing, intemperate drinking and licentious living. Thus wealth is not health; on the contrary, just the opposite is true.
\end{abstract}

Key-Words: Plutarch, Moralia, Greek Ethics, Roman Lives, Neo-Pythagoreanism.

ative. He certainly, and quite naturally,

Plutarch was certainly a quite well-todo gentleman who could afford practically anything he wanted. However, he clearly did not lead an extravagant way of life. His philosophical, basically Platonic, outlook made him estimate virtue and the pursue of knowledge higher than anything else. Besides these abstract values, however, he attached great importance especially to one concrete thing in the tangible world: health. Plutarch is a strenuous advocate of the traditional modest Greek way of life. It clearly appears that he supported the maxim mens sana in corpore sano both in theory and in his own real life. His outlook is to be seen in the genuine interest in medicine and in rules of a wholesome living, which he frequently shows in his writings, not least in the Quaestiones convivales.

Plutarch's attitude to wealth was basically critical, but not fundamentally negregards economical resources as a good thing; it is only the undue use of them for various kinds of excesses that he deprecates, often in severe words. $\mathrm{He}$ expresses his critical views at many places in his writings, and he also devoted particular essays to this theme. Two of these have come down to us, the denunciation of superfluous wealth, entitled De cupiditate divitiarum, and the deterring pamphlet De vitando aere alieno. Two other works in this field are listed in the Catalogue of Lamprias, $\mathrm{Nr}$.

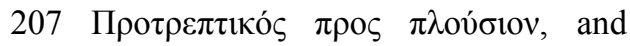

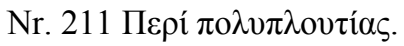

It was certainly natural for Plutarch to take this critical position towards wealth. As basically a Platonist he continues a long tradition within the Academy, and to some extent also the Peripatos and the Stoa ${ }^{1}$. But there is no

See references in Ph. H. de LACY and B. EINARson, Plutarch s Moralia, Vol. VII (LCL), Cambridge, Mass. \& London, 1968, pp. 2-4. 
reason to doubt that Plutarch is expressing his quite genuine feelings and thoughts when he denounces extravagance, gluttony, and luxurious living in general. He lived at a time when the living standards had reached a very high level, notably in the Roman upper classes. The widespread materialistic views naturally appeared repugnant to a person like Plutarch with his Platonic outlook and ethical ambition. But in fact he does not very often deliver criticism levelled precisely against contemporary luxury, although this is no doubt the target of his censure. He mostly prefers to express his denunciation of the misuse of money by the rich in general terms. However, in several passages it is possible to conclude upon the main target of the criticism, the Romans, and in the Vitae we find some examples of criticism of individuals.

To philosophers of all schools except the Hedonistic, it was self-evident that wealth should not be an end in itself. Money ought to be used and looked upon as a means to provide the indispensible necessities of life. Plutarch's basic reason for rejecting material abundance was its detrimental effects on the soul. Wealth inevitably produces love of

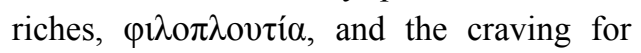
it, $\alpha \pi \lambda \eta \sigma \tau i \alpha$. In a fragment of TTepi $\pi \lambda o v$ tov Plutarch calls this craving a $\mu \alpha v i ́ \alpha$ and describes this psychic state as a kind of $\varepsilon v \theta 0 v \sigma 1 \alpha \sigma \mu$ ó $_{\text {, a strong word }}$ with religious connotations 2 . Insatiable money-getters suffer from a psychic dis-

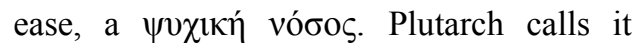
psychic poverty, $\pi \varepsilon v i ́ \alpha \quad \psi v \chi 1 \kappa \eta^{3}$. Unlike physical sufferings, which often can be cured, this one, like other psychic insufficiencies, is incurable 4 . And Plutarch asks: "From what other ills then does wealth deliver us, if it does not even deliver us from the craving for it?"5

The $\pi \varepsilon v i ́ \alpha$ $\psi v \chi 1 \kappa \eta$ of the rich is a very serious state of illness, according to Plutarch. This is because virtue is severely affected. Foolish people in particular are made worse through the influ-

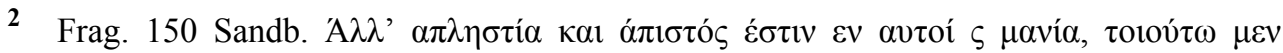

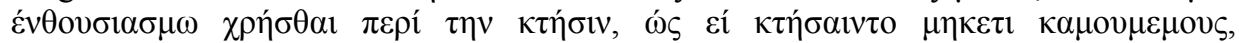

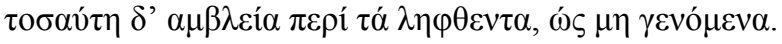

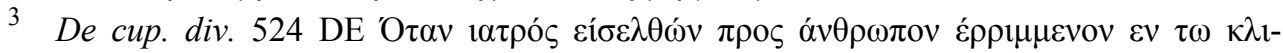

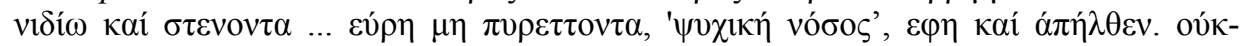

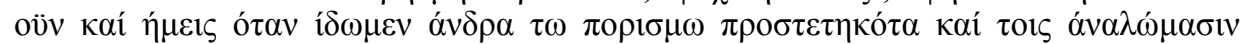

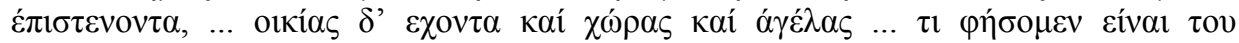

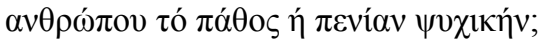

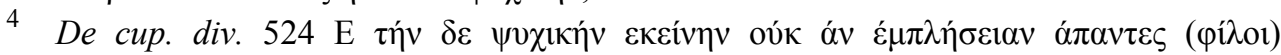

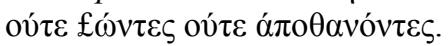

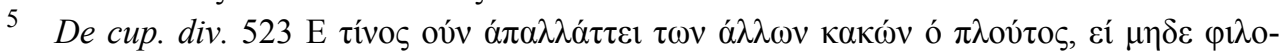
$\pi \lambda$ oviías; 
ence of money. The more un-intelligent a man is, the more extravagant are his excesses; there is a madness in his pleasures, and he has the means to gratify it ${ }^{6}$.

Plutarch regards this ruined state of the soul of the rich man as the most devastating consequence of the misuse of money. A life aiming at virtue, as he describes it in De virtute morali and in De profectibus in virtute, is precluded, and this means that a good and happy life is impossible. Plutarch emphasizes that a happy life does not come from external things at all. He states this by the end of De fortuna, and repeats it in the introduction to De virtute et vitio .

Far from bringing happiness, wealth is apt to be disastrous. The false expectations connected with it contain venom and devour the soul of the rich man and discompose it, causing insomnia and stinging desires ${ }^{8}$. Plutarch censures the wrongdoings that the rich commit in order to obtain wealth and he denounces the licientiousness which begets every sort of pleasure. It is right and proper to deprecate and loathe these pleasures because their presence engenders many distempers and emotions, like maggots and grubs, in men's souls?.

Although Plutarch is well aware of how difficult it is for rich people to avoid being addicted to the all-absorbing $\mu \alpha v i$ í of amassing more and more property, he does not give up his endeavour to forestall this inclination in his listeners and readers. After expressive warnings he holds up the philosophic way of life as the superb alternative. He writes: "Unless you lay level the emotions of your soul, put a stop to your insatiate desires and quit yourself of fears and anxieties, you are but decanting wine to a man in fever, or offering honey

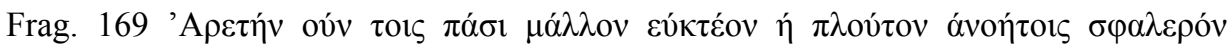

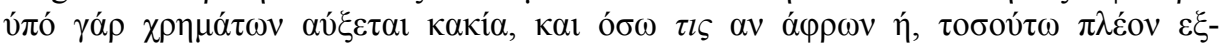

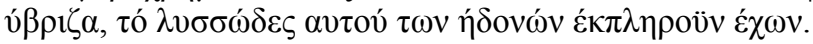

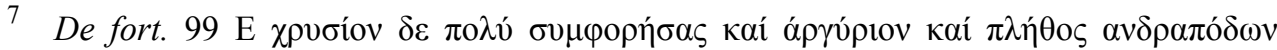

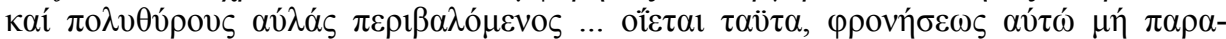

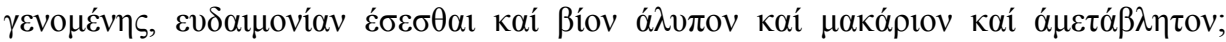

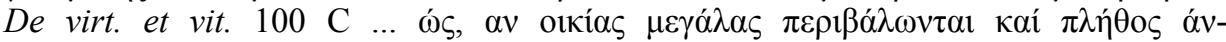

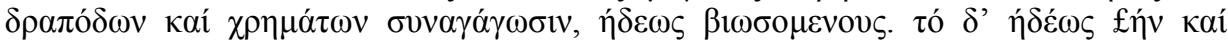

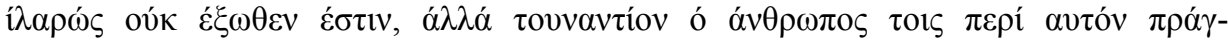

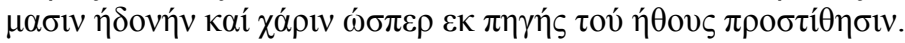

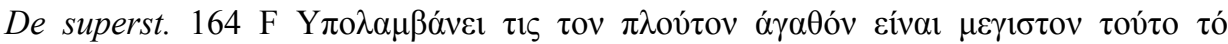

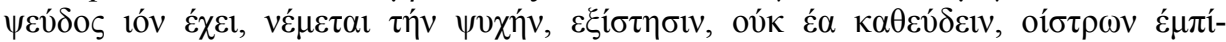

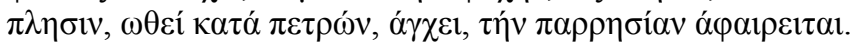

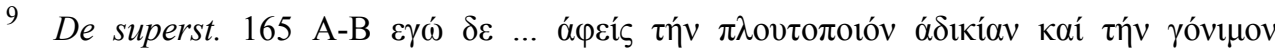

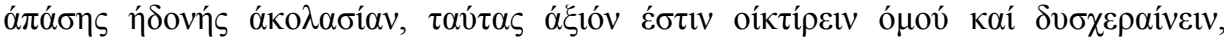

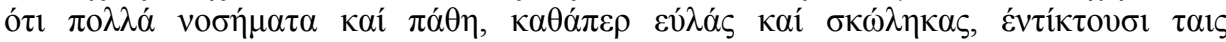
$\psi v \chi \alpha 1 \varsigma \pi \alpha \rho \circ \sigma^{\sigma} \alpha \nu$ 
to a bilious man."10 And he continues: "You will be contented with your lot if you learn what the honourable and good is. You will be luxurious in poverty, and live like a king.... If you become a philosopher, you will live not unpleasantly, but you will learn to subsist pleasantly anywhere and with any resources." 1 Living in modest circumstances fosters virtue, is Plutarch's message. Plutarch cites Arcesilaus who said that poverty, like Ithaca, is rough but a good nurse of men and an effective school of virtue ${ }^{12}$.

From Plutarch's philosophical point of view, then, mental and psychic health, which means $\alpha \rho \varepsilon \tau \eta \dot{n}$ proves to be real wealth. It also normally implies physical health, whereas the opposite, the $\psi v \chi \iota к \eta$ vóбo? of the rich, ruins the body together with the mind, through the love of pleasure. In a few fragments of his work

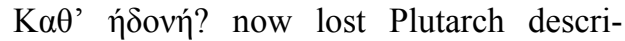
bes how pleasure relaxes and softens our bodies in continuous luxuries, and thus ensues an easy path for diseases, pains and premature old age ${ }^{13}$. He compares it to a beast that enslaves $\mathrm{us}^{14}$, and it betrays our virtue while it puts our selfcontrol to the torture ${ }^{15}$.

However, Plutarch is certainly not fundamentally negative to pleasure. $\mathrm{He}$ draws a perspicuous distinction between legitimate pleasures, which are in accordance with nature and should properly be called curative necessities, and all others, which are unnecessary violations of nature. He emphasizes that the natural law that governs the irrational animals should also govern us. We should provide ourselves with what we need according to nature and not desire more after satiety has been obtained ${ }^{16}$. Additional pleasures

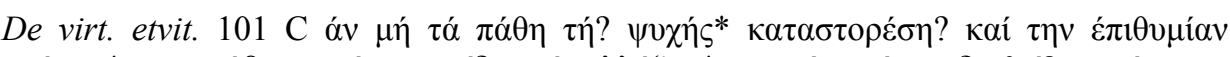

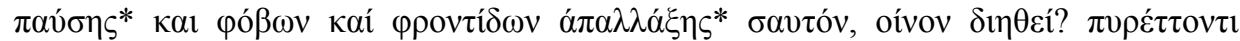

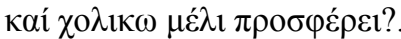

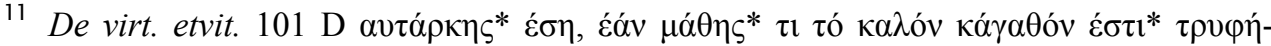

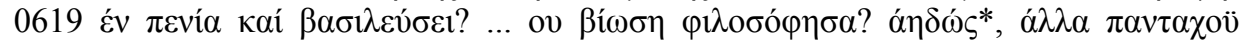

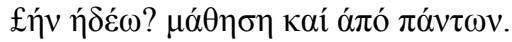

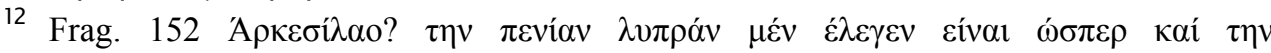

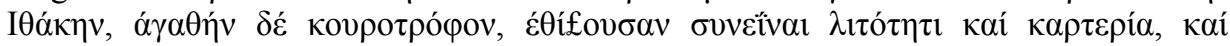

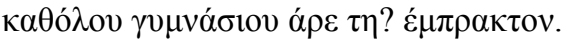

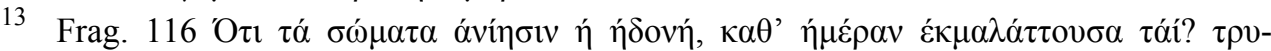

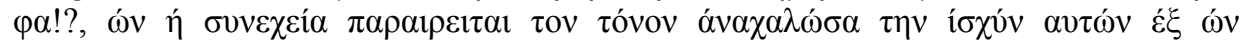

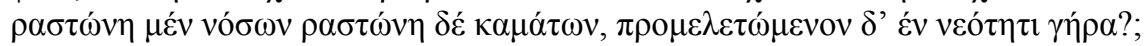

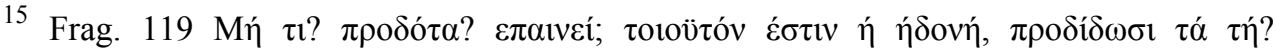

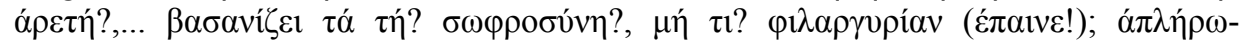

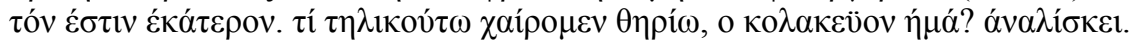

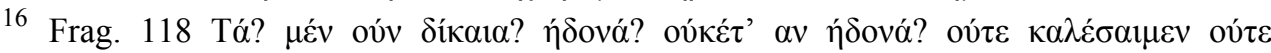

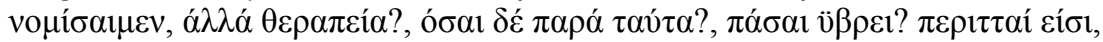


that the body achieves through being prodded by the mind are equally unnatural as the effects produced by the tickling of the arm-pits: they are deranging and disturbing and foreign to nature ${ }^{17}$.

Plutarch repeatedly underlines that psychic and physical health go together. We have observed, however, that he considers psychic health primary and actually a prerequisite of bodily health. It can be

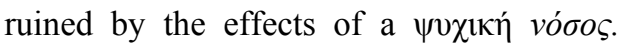
But of course bodily health has a value in itself. Plutarch points out that the body assists the mind in its work and that therefore we should repay it by giving it good care and attention and consider that the fairest of the good gifts which a fair and lovely health bestows is the unhampered opportunity to get and to use virtue both in words and deeds ${ }^{18}$. He even designates health, rather amusingly, as being the most divine and agreeable sauce ${ }^{19}$.

The obviously great interest in healthy life shown by Plutarch was a contemporary trend. This was a natural reaction to the excesses and luxury in which rich people of his time indulged. Gormandizing, intemperate drinking and licentious living were widespread in the upper classes, especially among the Romans, but also to some extent in Greece. Plutarch gives some indications of this in the Quaestiones convivales, for example in VII5 where the rich Callistratus gives an extravagant banquet with entertainment by a dancing-group, and IV 1 where the elaborate variety of food provided at the dinner was conspicuous and caused reactions and discussions. One of the guests, Philinus, who was present together with his young son, protested against the extravagance and opted for simple, unsophisticated food. He was most probably a Pythagorean and consequently a vegetarian.

In Plutarch's time Neo-Pythagoreanism developed into a rather widespread philosophical movement, presumably because of its demands for a restricted way of living, opposed to the contemporary increasing tendency of a mentally and physically unhealthy life style.

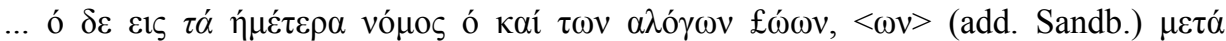

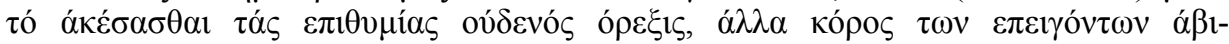

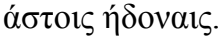

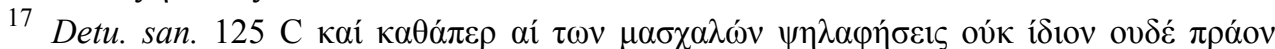

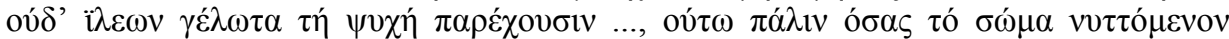

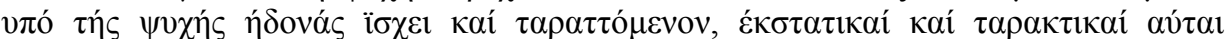

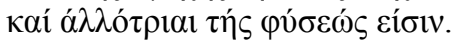

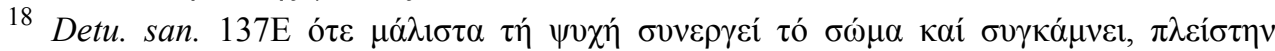

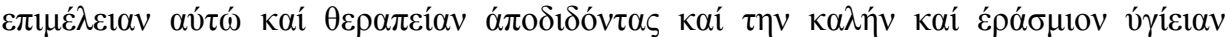

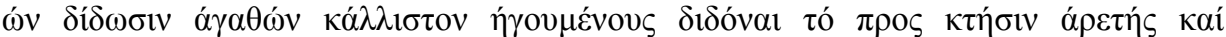

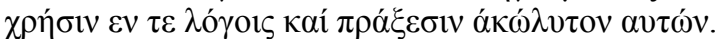

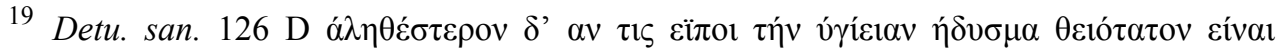

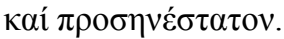


Plutarch himself was influenced by the Pythagorean doctrines. In Quaestiones convivales II 3, $635 \mathrm{E}$, he mentions that he, because of a dream, for a long time had abstained from eating eggs. Other guests then suspected him of being committed to Orphic or Pythagorean beliefs. And he says nothing to refute their opinion. Plutarch also shows his positive attitude and good knowledge of Pythagorean thinking in the two discussions in VIII 7 and 8 on the precepts and the vegetarianism of this sect.

Already as a young man Plutarch was inspired by the Neo-Pythagorean philosophy and the ethics of Theophrastus, so as to take the position of vegetarianism and to be an advocate of the rights of the animals ${ }^{20}$. In De esu carnium he argues in a youthful, aggressive way against the eating of flesh, starting with a rhetorical question: "And you really ask by what reason Pythagoras abstained from flesh?" And he replies: "For my part I rather wonder in what emotion and in what state of soul or mind the first man touched his mouth to gore and brought his lips to the flesh of a dead creature."21

To judge from a passage in De esu carnium, Plutarch had personally experienced disgust at the gluttony prevalent at rich men's banquets. He writes: "What a terrible thing it is to look on when the tables of the rich are spread, men who employ cooks and spicers to groom the dead! And it is even more terrible to look on when they are taken away, for more is left than had been eaten. So the beasts died for nothing!"'22

The luxury leads to the craving for constantly more elaborate taste sensations. Plutarch describes in detail how this gives rise to gruesome torturing of the animals. "It is current practice," he writes, "that some people thrust red-hot spits into the mouth of swine, so that by the plunging of the iron the blood may be emulsified and, as it circulates through the body, may make the flesh tender and delicate. Others jump upon the udders of sows about to give birth and kick them so that, when they have blended together blood and milk and

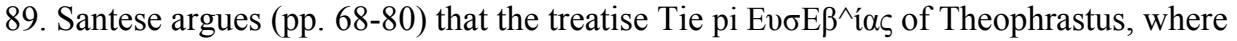
he maintains the communio iuris of animals and human beings, was decisive of Plutarch's thinking about these matters.

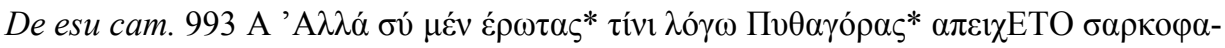

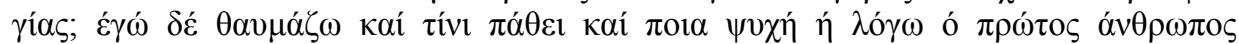

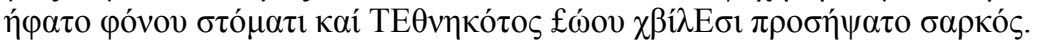

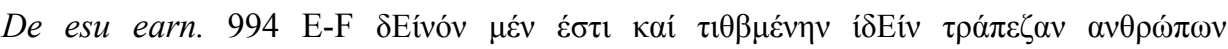

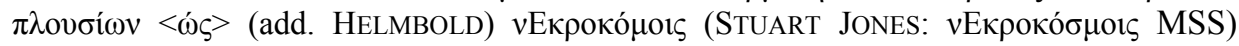

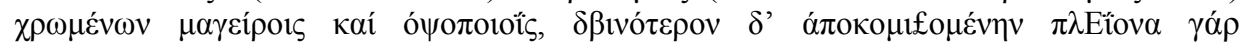

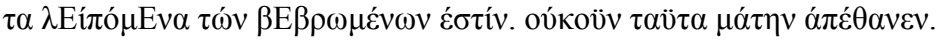


gore and the unborn young have at the same time been destroyed at the moment of birth, they may eat the most enflamed part of the creature. Still others sew up the eyes of cranes and swans, shut them up in darkness and fatten them, making the flesh appetizing with strange compounds and spicy mixtures." 23

It is perfectly evident, Plutarch concludes, that these practices result from satiety and insolence and luxury, and have made the lawlessness into a pleasure ${ }^{24}$.

And furthermore, Plutarch argues, the cruelty due to intemperance in eating becomes an inveterate habit that infects even other organs of sense with licentiousness. The art of hearing falls sick, corrupting musical taste, and the sight is depravated so as to regard the slaughter and death of men and animals, their wounds and combats, as the most precious sort of spectacle ${ }^{25}$. Plutarch refers to the gladiatorial combats, and in his deprecating attitude he sides with most Greek intellectuals who loathed this barbarious Roman custom ${ }^{26}$.

But Plutarch goes still further in his condemnation saying: 'Thus, having gradually hardened the edge of our insatiable appetite, they have advanced to wars and the slaughter and murder of human beings." 27

There can be no doubt that Plutarch's censure of luxury was directed mainly against the Romans, although he usually expresses his criticism in general terms, or else as hints and insinuations. Only in a few cases he overtly condemns dissolute and unbridled behaviour in named Romans, for example Antony: "(Men of worth and uprightness) loathed his ill-timed drunkenness, his heavy expenditures, his debouches with women, his spending the days in sleep, or in wandering about with crazed and aching head, the nights in revelry or at shows, or in attendance at the nuptial feasts of mimes and jesters. It is said, at any rate, that he once feasted at the nuptials of Hippias the mime, drank all night, and then, early in the morning, when the people summoned him to the forum, came before them still surfeited with food and vomited into his toga, which one of his friends held at his service." 28 
Plutarch regards the detrimental influence of the flatterers surrounding the leaders as highly responsible for their perverted customs. In the essay How to tell a flatterer from a friend he writes: "The praise which accustoms a man to treat vices as virtues, so that he feels not disgusted with them but delighted, and which also takes away all shame for his errors...; this it is that all but subverted and destroyed the character of the Romans in those days, by trying to extenuate Antony's luxuriousness, his excesses and ostentatious displays."

However, Plutarch also observes that the relations between flatterers and men of power is mutual. He takes Sulla as an example, stating that "there was no measuring what he lavishly squandered and threw away upon his flatterers." ${ }^{30}$ Plutarch reports about his revelling in his old days and the consequences it had: "Sulla consorted with actresses, harpists and theatrical people, drinking with them on couches all day long.... By this mode of life he aggravated a disease which was insignificant in its beginnings, and for a long time he did not know that his bowels were ulcerated. This disease corrupted his whole flesh also, and converted it into worms, so that although many were employed day and night in removing them, what they took away was as nothing compared with the increase of them" 31 .

As for the squandering of money, a common vice of rich men, Plutarch takes Crassus as a typical case: his craving for money obscured his many virtues $^{32}$ and, he writes, "Nicias' possessions and expenditures were not a tithe of what Crassus expended when he feasted so many myriads of men, and then furnished them with food afterwards; so one is amazed that anyone could fail to perceive that vice is a sort of inequality of character, when he sees men amassing money shamelessly and then squandering it uselessly." 33

Completely different from the conduct of Crassus was that of Caesar: "He was not amassing wealth from his wars for his own luxury or for any life in ease, but he treasured it up carefully as common prizes for deeds of valour." 34

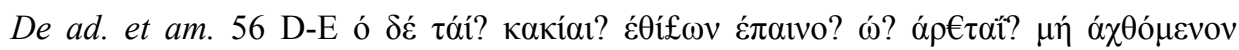

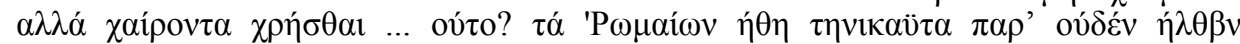

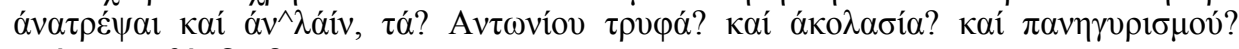
... v́локорt£́́ $\mu € v o$ ?

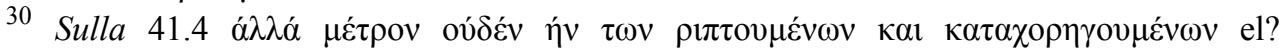

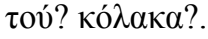

31 Sulla 36.1-3. The disease is the phthiriasis/morbus pediculosis, louse disease.

32 Crass. 2.1.

33 Crass. 34.4.

34 Caes. 17.1. 
Another famous Roman who receives Plutarch's great approval is Cato the Younger, who "amidst the great effeminacy and luxury of those who took part in his campaign, displayed such good discipline, self-control, courage in all emergencies, and sagacity that men thought him not one whit inferior to the elder Cato"35. Also Pompey is praised for his modest and temperate way of living, and for his simplicity and indifference in matters pertaining to the table ${ }^{36}$.

The notorious gormandizer, Lucullus, is bestowed a rather surprisingly lenient judgement. Plutarch records that after his military activities he gave himself up to all kinds of luxury and gormandizing . But in Plutarch's view, these bad habits of his old age can to a large extent be excused on the ground that he was fond of philosophy, especially the Old Academy, and possessed a well-stocked library which he kept open to all and where the Greeks who visited Rome constantly repaired "as to an hostelry of the Muses" 38 . And Plutarch sums up: "Had he ended his days in active military command, not even the most carping and censorious spirit, I think, could have brought accusation against him." By this judgement Plutarch shows himself as not being a narrow-minded moralist. He was able to disregard the bad habits of the old Lucullus probably because that man was a person who possessed qualities that appealed to Plutarch, intellectual interests, agreeable manners, and a sociable character.

In the case of Cicero, Plutarch's positive judgement was of course natural: he notes that Cicero lived in a generous and at the same time modest manner ${ }^{40}$. Plutarch emphasizes that Cicero succeeded to remain steadfast in his contempt for wealth, at a time when the love of wealth was at its greatest height ${ }^{41}$.

To sum up, we may confirm, that Plutarch had a philosophical, basically Platonic, outlook on wealth. Money should not be made an end in itself, and not be estimated to a higher value than anything else. Plutarch instead establishes that by means of a philosophically founded ethical attitude to life it is possible to obtain the optimal state of mental, psychic, and physical health. This is the basic prerequisite for all sorts of virtue, and this is what Plutarch regards as real wealth.

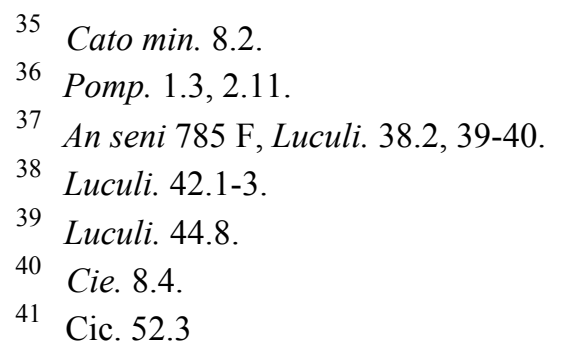

